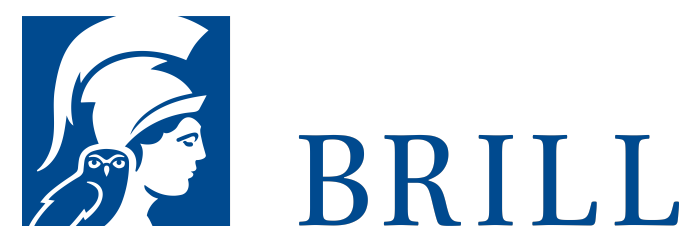

\title{
Kunst als soziale Konstruktion
}

Authors: Hans-Dieter Huber and Hans Dieter Huber

In Kunst als soziale Konstruktion beschreibt Hans Dieter Huber, die Bildende Kunst aus der Perspektive der Systemtheorie und des Radikalen Konstruktivismus und entwickelt so ein neues Verständnis der Rolle von Kunst in der modernen Gesellschaft.

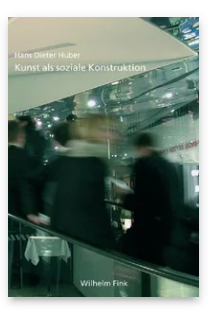

Pages: 408

Seiten, 86 s/w

Abb.

Language:

German

Subjects:

General, Art

History

Publisher: Brill |

Fink

E-Book (PDF)

Released online:

29Jan 2020

ISBN: 978-3-

8467-4426-o

List price

USD $\$ 63.00$

Paperback

Publication date: O5 Oct 2007

ISBN: $978-3-$ 7705-4426-4 List price USD $\$ 63.00$ 
For more information see brill.com

Order information: Order online at brill.com +44330 333 0049 | customerservices@brill.com Submission information: brill.com/authors

Titles published by Brill | Fink, Brill | mentis or Brill | Schöningh: +49(o)715413279216| brill@brocom.de 